\title{
The Effects of Volcanic Ash on The Strength and Permeability Mortar
}

\author{
Fitro Darwis, Ilham Banggu \\ Civil Engineering Department \\ Universitas Pasific \\ Morotai, Indonesia
}

\author{
Mufti Amir Sultan ${ }^{1}$ \\ Civil Engineering Department \\ Universitas Khairun \\ Ternate, Indonesia \\ 1'muftiasltn@unkhair.ac.id
}

\begin{abstract}
Cement replacement materials have been widely used to reduce adverse environmental impacts, increase the strength and durability of concrete, such as fume silica, slag, fly ash or natural pozzolan (volcanic ash). Volcanic ash is material that released from the earth when volcanic eruptions occur. Volcanic ash becomes an important environmental issue because it disturbs the balance of the environment. Volcanic ash is a very fine pyroclastic material, has a characteristic form of diversity. In the field of engineering, the usage of volcanic ash as added ingredients is still very limited, while active volcanoes emit volcanic ash every year. The purpose of this study is to determine the effect of added materials-volcanic ash of Dukono mountain to the mortar mixture. In this research, the test of compressive strength and mortar absorption. This research uses added material- volcanic ash from Dukono mountain. Preparation of test specimens with FAS value 0.4 with volcanic ash composition $0 \%, 5 \%, 10 \%, 15 \%, 20 \%$ and $25 \%$ to the weight of cement. The results of the compressive strength test average mortar with the composition of volcanic ash as added ingredients, increased compressive strength with the addition of volcanic ash composition of 5\% and $10 \%$ of $21.73 \mathrm{MPa}$ and $30.40 \mathrm{MP}$. Added volcanic ash of $15 \%, 20 \%$, and $25 \%$ respectively decreased compressive strength of $24.27 \mathrm{MPa}, 18.13 \mathrm{MPa}$, and 16.26 MPa, respectively. The best composition for the usage of volcanic ash as an additive material at $10 \%$ to the weight of cement.
\end{abstract}

Keywords—volcanic ash; mortar; compressive stress

\section{INTRODUCTION}

Cement replacement materials have been widely used to reduce adverse environmental impacts, increase the strength and durability of concrete, such as fume silica, slag, fly ash or natural pozzolan (volcanic ash). Volcanic ash is one of the alternative cement replacement materials, which has been widely researched and that can be useful in concrete mixes. Utilization of volcanic ash for high-quality concrete manufacture, from the results of the study stated that the addition of volcanic ash as a mixture on the concrete of both the size of 100 mesh and micro size can produce high-quality concrete is lightweight with high density [1]. The usage of volcanic ash in concrete mixtures, the analysis results show that substituting fine aggregates of $20 \%$ volcanic ash will increase concrete compressive strength by $10 \%$ for brown volcanic ash and $15 \%$ for yellow volcanic ash [2]. The usage of volcanic ash at certain concentrations will improve the properties of concrete. The usage of metakaolin and volcanic ash in a mixture of Portland cement, the study recommends that meta kaolin and volcanic ash can be mixed in amounts of up to $30 \%$ each of cement weight [3]. The usage of volcanic ash Gamalama mountain added materials can improve the properties of concrete [4]. The usage of volcanic ash of Jebel Marra on mortar mix will increase the performance [5]. Volcanic ash is a material that released from the bowels of the earth when volcanic eruptions occur, volcanic ash can be transported by wind and water to a great distance from the volcano's location. Volcanic ash becomes an important environmental issue because of its considerable amount and disturbs the environmental balance. Volcanic ash is a very fine pyroclastic material and has various shape characteristics. In the field of engineering, the use of volcanic ash added ingredients is still very limited, while active volcanoes emit volcanic ash every year very much. Research into the use of Jordanian volcanic tuffs in mortar mixtures, by adding Jordanian volcanic tuffs in a suitable ratio will improve the characteristics of cement mortar [6]. The study used volcanic ash from Holili as a substitute for cement, stating that volcanic ash can be used to reduce the amount cement in a concrete mixture [7].

North Maluku has 5 active volcanoes. These mountains have potential for the eruption, one of them is Dukono, which is a volcano located North Halmahera District. Dukono mountain last erupted on July 25, 2017, although it did not cause damage and casualties but leaves a lot of volcanic ash.

In the field of engineering, the usage of volcanic ash as added ingredients is still very limited, while active volcanoes emit volcanic ash every year. The purpose of this study is to determine the effect of added materials-volcanic ash of Dukono mountain to the mortar mixture.

\section{MORTAR}

Mortar is defined as a mixture of materials, consists of fine aggregates (sand), adhesives (clay, limestone, portland cement) and water with certain compositions. Mortar has a relatively small depreciation value. The sheer force of the mortar should be able to carry the forces that acting on the mortar as well as the mortar must be resistant to water absorption since the mortar will harden quickly if the water absorption on the mortar is too large. 
The mortar specification shall comply with the requirements of the material and testing requirements. The mortar specification consists of two [8], namely: Specification proportion and Specification of properties.

Mortars prepared in the laboratory must consist of a mixture of binder materials that are cement, aggregate, and water. The composition of mortar must meet the requirements of specifications such as Table 1 .

TABLE I. REQUIREMENTS SPECIFICATION OF PROPERTIES MORTAR

\begin{tabular}{|c|c|c|c|c|c|}
\hline No & Mortar & $\begin{array}{l}\mathbf{T} \\
\mathbf{y} \\
\mathbf{p} \\
\mathbf{e}\end{array}$ & $\begin{array}{l}\text { Average } \\
\text { compressive } \\
\text { strength } \\
\text { (MPa) }\end{array}$ & $\begin{array}{l}\text { Minimum } \\
\text { water } \\
\text { retention } \\
(\%)\end{array}$ & $\begin{array}{c}\text { Maximum Air } \\
\text { Content } \\
(\%)\end{array}$ \\
\hline & \multirow{4}{*}{ Lime } & M & 17.2 & 75 & 12 \\
\hline & & $S$ & 12.4 & 75 & 12 \\
\hline & & $\mathrm{N}$ & 5.2 & 75 & $14 b j$ \\
\hline & & $\mathrm{O}$ & 2.5 & 75 & $14 \mathrm{bj}$ \\
\hline & \multirow{4}{*}{ Cement } & M & 17.2 & 75 & ........c) \\
\hline & & S & 12.4 & 75 & ........c) \\
\hline & & $\mathrm{N}$ & 5.2 & 75 & .......c) \\
\hline & & $\mathrm{O}$ & 2.4 & 75 & .......c) \\
\hline
\end{tabular}

\section{A. Compression Strength of Mortar}

The compressive strength of mortar is the maximum force of broad unity. The workforce on a mortar specimen is in the form of a cube of a certain size and a certain age [8]. The compressive strength of mortar is represented by the maximum compressive strength with $\mathrm{MPa}$ units. The compressive strength of mortar is strongly influenced by water, mixed proportions. The lower the cement water factor, the higher the compressive strength. However, if the cement water factor is low, it is very difficult in the process. The mortar compressive strength formula is as below:

$$
\sigma_{m}=\frac{P_{m a k s}}{A}
$$

where:

$\sigma \mathrm{m}=$ mortar compressive strength $(\mathrm{MPa})$

Pmax $=$ maximum compressive force $(\mathrm{N})$

$\mathrm{A}=$ the cross-sectional area of the specimen (mm2)

Cement water ratio, cement number, mortar age, and aggregate properties are factors that strongly gives influence to the compressive strength of mortar.

\section{B. Cement Water Ratio (FAS)}

In general, the minimum FAS value is given around 0.4 0.65. To find out the FAS in the mortar, it needs a comparison between the amount of water and the amount of cement in a mortar or concrete mixture. High FAS values cause lower concrete quality, but if a low FAS value will also cause difficulties in the process. Low FAS values do not necessarily mean that the strength of concrete is higher. Mortar strength is not necessarily high if there is more cement content. This is due to the large amount of water, as well as cement paste can cause more porous than mortar with less cement content. Because of its porous content which can reduce mortar strength. The amount of cement in mortar must also have certain optimum values in order to provide high compressive strength.

In addition to the cement water factor and the amount of cement, mortar age is very important role in the compressive strength of mortar. After 28 days can obtain the desired strength. The shape, the hardness of the surface, the hardness and the maximum size of the aggregate are the aggregate properties that affect the mortar strength.

\section{Volcanic Ash}

Volcanic ash is a mineral of volcanic rock which has a size of approximately $2 \mathrm{~mm}$ (1/2 inch). Volcanic ash is the result of volcanic eruptions. The ash particles are very small with a cross-sectional size smaller than $0.001 \mathrm{~mm}$. Volcanic ash is formed during explosive volcanic eruptions. The explosive eruption occurs when the gas dissolves in molten rock (magma) which expands and releases explosively into the air, and also when the water is heated by the magma and releases suddenly into steam. The gas release force loudly breaks a solid rock. The expanding gas also pushes the magma and explodes into the air, then when it freezes it forms into fragments of volcanic rock and glass.

Volcanic ash is currently still used in various countries such as Egypt, Italy, Germany, Mexico, and China. Volcanic ash can reduce costs and improve the quality and durability of concrete. When volcanic ash causes deep cementation, it will transform into the soft rock called (Tuff).

\section{METHODOLOGY}

\section{A. Tools and Materials}

The tools that used in this study are: scales, standard sieves, water tanks, $100 \mathrm{ml}$ measuring cups, mortar molds, ASTM standard mixing machines [9] (ASTM C305) with adjustable rotation speed, equipped with stirrer bowl, standard complete melting table ASTM [10] (ASTM C230 with melting ring and mortar press test machine. The materials that used are: Portland cement, sand, volcanic ash, fresh water.

\section{B. Specimen}

The cement that used for this mortar mixture is cement type 1 . Other types of cement can also be used in accordance with the needs and circumstances of the job. Under normal circumstances, this cement is not tested, using the test data carried out by the manufacturer. The sand used directly is used without prior screening from Kalumata quarry. The volcanic ash used was separated first from dirt, volcanic ash was taken 
from the area of Dukono mountain, North Halmahera Regency.

The specimens that used were $5 \times 5 \times 5 \mathrm{~cm}$ with a composition of 1 cement: 4 sand with FAS 0.4, the matrix of the test objects is presented in Table II. The specimens used were $5 \times 5 \times 5 \mathrm{~cm}$ with a composition of 1 cement: 4 sand with FAS 0.4, the matrix of the test objects is presented in Table II.

TABLE II. THE MATRIX OF THE SPECIMEN

\begin{tabular}{|c|c|c|c|}
\hline No & Specimens & $\begin{array}{c}\text { Vulkanic Ash Compotition } \\
\text { (\%) }\end{array}$ & $\begin{array}{c}\text { Amount } \\
\text { (pcs) }\end{array}$ \\
\hline 1. & $\mathrm{MVT}_{1}$ & 5 & 10 \\
\hline 2. & $\mathrm{MVT}_{2}$ & 10 & 10 \\
\hline 3. & $\mathrm{MVT}_{3}$ & 10 & 10 \\
\hline 4. & $\mathrm{MVT}_{4}$ & 15 & 10 \\
\hline $\mathbf{5 .}$ & $\mathrm{MVT}_{5}$ & 20 & 10 \\
\hline 6. & $\mathrm{MVT}_{6}$ & 25 & 10 \\
\hline
\end{tabular}

\section{RESUlT AND DisCUSSION}

\section{A. Mineral Composition of Dukono Volcanic Ash}

$\mathrm{X}$-ray diffraction test results are presented in Figure 1 and Table 3. The dominant elements are $\mathrm{Si}, \mathrm{Fe}$ and $\mathrm{Ca}$.

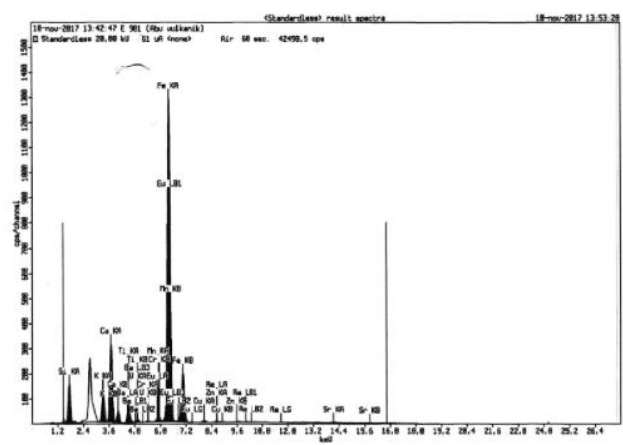

Fig. 1. Dukono volcanic ash diffraction pattern

TABLE III. THE MATRIX OF THE SPECIMEN

\begin{tabular}{|c|c|c|}
\hline No & Compound & Concentration Unit (\%) \\
\hline 1 & $\mathrm{Si}$ & 39,1 \\
\hline 2 & $\mathrm{~K}$ & 6,40 \\
\hline 3 & $\mathrm{Ca}$ & 16,0 \\
\hline 4 & $\mathrm{Ti}$ & 2,12 \\
\hline 5 & $\mathrm{~V}$ & 0,12 \\
\hline 6 & $\mathrm{Cr}$ & 0,068 \\
\hline 7 & $\mathrm{Mn}$ & 0,58 \\
\hline 8 & $\mathrm{Fe}$ & 33,7 \\
\hline 9 & $\mathrm{Cu}$ & 0,25 \\
\hline 10 & $\mathrm{Zn}$ & 0,04 \\
\hline 11 & $\mathrm{Sr}$ & 0,66 \\
\hline 12 & $\mathrm{Ba}$ & 0,2 \\
\hline
\end{tabular}

\begin{tabular}{|c|c|c|}
\hline No & Compound & Concentration Unit (\%) \\
\hline 13 & $\mathrm{Eu}$ & 0,4 \\
\hline 14 & $\mathrm{Re}$ & 0,3 \\
\hline
\end{tabular}

\section{B. Absorption of Mortar}

Based on the result of water absorption testing for the proportion of $1 \mathrm{pc}$ : $4 \mathrm{ps}$, it was obtained information that water absorption decreased along with the increasing composition of the usage of Dukono volcanic ash in the mixture, shown as in Figure 2.

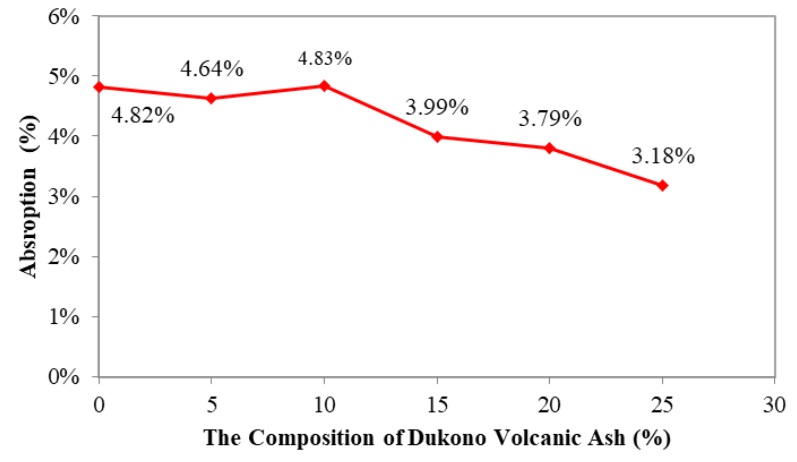

Fig. 2. Dukono volcanic ash diffraction pattern

Figure 2 shows the addition of Dukono volcanic ash to the mortar mixture with a composition of $0 \%, 5 \%, 10 \%, 15 \%$, $20 \%$ and $25 \%$. With the addition of Dukono volcanic ash, the absorption of mortar tends to decrease. This indicates that the addition of Dukono volcanic ash causes the mortar cavity to be smaller because the Dukono volcanic ash is a filler which closes the cavity.

\section{The Compressive Strength of Mortar}

Figure 3 shows the relationship of Dukono volcanic ash composition as an added material with a mortar compressive strength. There is an increase in compressive strength with the addition of 5\% Dukono volcanic ash composition and $10 \%$ of $21.73 \mathrm{MPa}$ and 30.40 MP. However, Dukono volcanic ash additions of $15 \%, 20 \%$, and $25 \%$ respectively decreased compressive strength of $24.27 \mathrm{MPa}, 18.13 \mathrm{MPa}$, and 16.26 MPa respectively.

The percentage change in compressive strength to the composition of the Dukono volcanic ash as added material as shown in figure 4. From the picture it can be seen that with the added Dukono volcanic ash material to cement the percentage of compressive strength decreases to reach the composition of the composition of $10 \%$ with an increase in compressive strength of $54.05 \%$, but after $20 \%$ there is a decrease in compressive strength against strong mortar without material added by $8.11 \%$. 


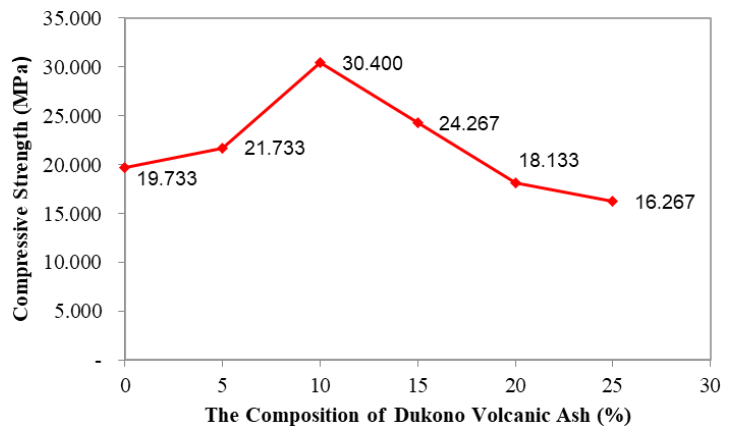

Fig. 3. Dukono volcanic ash diffraction pattern

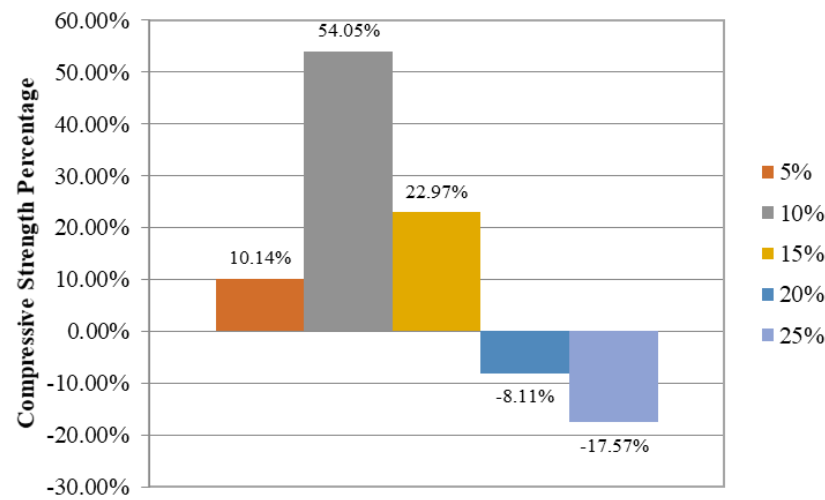

Fig. 4. The Relationship between Dukono volcanic ash composition and mortar compressive strength

\section{CONCLUSION}

From the results of the research and discussion, some conclusions can be drawn as follows:

The relationship of AVD composition as an ingredient added with mortar compressive strength, where there was an increase in compressive strength with the addition of AVD composition of $5 \%$ and $10 \%$ at $21.73 \mathrm{MPa}$ and $30.40 \mathrm{MP}$. However, the addition of AVD by $15 \%, 20 \%$, and $25 \%$ decreased the compressive strength of $24.27 \mathrm{MPa}, 18.13 \mathrm{MPa}$, and $16.26 \mathrm{MPa}$ respectively. The best composition for the use of AVD as an ingredient added to $10 \%$ of the cement amount.

AVD as an ingredient that added to the mortar mixture with a composition of $0 \%, 5 \%, 10 \%, 15 \%, 20 \%$ and $25 \%$. With the addition of AVD, the absorption of mortar tends to decrease, this indicates that the addition of AVD causes the mortar cavity to be smaller because AVD is a filler which closes the cavity.

\section{REFERENCES}

[1] B.J. Olawuyi and K.O. Olusola, "Compressive Strength of Volcanic Ash/Ordinary Portland Cement Laterized Concrete," Civ. Eng. Dimens., vol. 12(1), pp. 23-28, 2010.

[2] M.A. Sultan, Imran, and Siswoko, "Kapasitas Lentur Balok Beton dengan Bahan Tambah Abu Vulkanik Gunung Gamalama," Technol., vol. 6(1) pp. 18-26, 2017.

[3] E.J.I. Kamang and M. Oyemogum, "Volcanic Ash, Metakaolin and Ordinary Portland Cement Blends in Concrete Production," Central Europe Toward Suistainable Building (CESB13), Prague, pp. 1-4, 2013.

[4] Imran, M.A. Sultan, J.S. Tuahuns, "Penggunaan Bahan Tambah Abu Vulkanik Gunung Gamalama Terhadap Perilaku Beton pada Daerah Lingkungan Laut," Techno., vol. 6(1), pp. 11-17, 2017.

[5] E.S. Ibrahiem and S.A. Ahmed, "Evaluation of Jebel Marra Volcanic Ash as Supplementary Cementitious Material for Use in Blended Cements," IOSR J. Eng., vol. 4(03), pp: 31-37, 2014.

[6] J. Al-Zou and K.K. Al-Zboon, "Effect of volcanic tuff on the characteristics of cement mortar", Cerâmica, vol. 60(354), pp 279-284, 2014.

[7] Badan Standardisasi Nasional. "SNI 03-6825-2002 Metode Pengujian Kekuatan Tekan Mortar Semen Portland untuk Pekerjaan Sipil”, Jakarta.

[8] Badan Standardisasi Nasional. "SNI 03-1968-1990 Metode Pengujian Analisa Saringan Agregat Halus dan Kasar", Jakarta.

[9] ASTM International, "ASTM C305-06: Standard Practice for Mechanical Mixing of Hydraulic Cement Pastes and Mortars of Plactic Consistency", United States.

[10] ASTM International, "ASTM C230/230M-14: Standard Specification for Flow Table for Use in Tests Of Hydraulic Cement”, United States. 